\title{
Lack of adult novel northern lineages of invasive green crab Carcinus maenas along much of the northern US Atlantic coast
}

\author{
Larissa M. Williams ${ }^{1,2, *}$, Camilla L. Nivison ${ }^{1}$, William G. Ambrose Jr., ${ }^{1,3}$, \\ Rebecca Dobbin ${ }^{1}$, William L. Locke $\mathrm{V}^{1}$ \\ ${ }^{1}$ Department of Biology, Bates College, Lewiston, ME 04240, USA \\ ${ }^{2}$ The Mount Desert Island Biological Laboratory, Salisbury Cove, ME 04609, USA \\ ${ }^{3}$ Akvaplan-niva, FRAM - High North Research Centre for Climate and the Environment, 9296 Tromsø, Norway
}

\begin{abstract}
Introduced over 200 yr ago to the east coast of North America, Carcinus maenas now ranges from New York to Newfoundland. In the 1980s, a secondary invasion of European lineages, termed northern haplotypes, occurred in Nova Scotia. Young-of-the-year sampled in 2007 revealed that northern haplotypes were present in low frequencies at several northwestern Atlantic sites as far south as New York; a model predicted an increase in their range and frequency over time. We collected samples in 2013 and 2014 to determine the haplotypes of adult crabs from New York to Nova Scotia. Six haplotypes, encompassing previously identified northern and southern haplotypes, 1 novel southern haplotype, and 1 Scandinavian haplotype, were identified in 275 crabs sampled at 11 sites. Northern haplotypes were only found in Nova Scotia, Beals Island (Maine), and Mount Desert Island (Maine) at a frequency of 60, 8, and $24 \%$, respectively; remaining sites were predominantly composed of a previously identified southern haplotype. Northern haplotypes are limited in adult crabs to Mount Desert Island and north, indicating that the southern haplotype is selectively favored at some point during their life history, recruitment of northern larvae is limited south of Mount Desert Island, or entire year-classes post-2007 were lost. Our results do not support the predictions of an increase in the range and frequency of northern haplotypes, at least among adults, and indicate that a more complete knowledge of factors affecting C. maenas life stages is necessary to understand the current distribution of haplotypes.
\end{abstract}

KEY WORDS: Carcinus maenas · Population genetics · Mitochondrial DNA - Invasive species · Range

\section{INTRODUCTION}

Modification of marine ecosystems through the invasion of exotic species has been identified as a critical issue facing the world's oceans (Carlton 1998). By successfully establishing themselves in foreign ecosystems, invaders can upset ecosystem processes such as primary production and nutrient cycling (Vitousek et al. 1996) as well as established feedback systems that maintain biodiversity and a stable community structure (Parker et al. 1999). One method for determining the establishment and spread of an invasive species is examining the genetics of their populations.

Population genetics predicts that the further apart 2 populations exist spatially, the more differentiated they should be at neutral genetic markers due to stochasticity. This correlation is often blurred by disruptions in patterns of gene flow caused by high migration rates and species invasions, such that invasive species often do not show classic phylogeographical distributions in non-native ranges (Novak \& Mack 
2005, Wares et al. 2005, Kolbe et al. 2007, Pringle et al. 2011, Gaither et al. 2013, Darling et al. 2014). The most important factor in the establishment of an invasive population may be propagule pressure, or the number of adult or larval individuals released into a non-native range (Allendorf \& Lundquist 2003, Lockwood et al. 2005). Rapid population expansion following invasion events (Tepolt et al. 2009) and multiple invasions from different source populations may also aid in invasion success by mitigating diversity lost by genetic drift from the source population (Roman \& Darling 2007, Darling et al. 2014). Despite empirical and theoretical work in the population genetics of invading species, it is still unclear which of these factors is most important in establishing, maintaining, and increasing populations of marine invaders.

The European green crab Carcinus maenas is a prime example of a successful marine invader, establishing along all continents with temperate coasts during the past 2 centuries (Compton et al. 2010). The crab was first discovered on the northeastern coast of the United States in 1817 in New York and southern Massachusetts, and it subsequently migrated north, reaching Casco Bay, Maine in the early 20th century (Audet et al. 2003, Carlton \& Cohen 2003). By the 1950s, green crabs were observed in Canada in Passamaquoddy Bay and the Bay of Fundy, from where they expanded over the next $50 \mathrm{yr}$ to the Atlantic coast of Nova Scotia and the Gulf of St. Lawrence (Audet et al. 2003). Since that time, there has been an increase in Canadian populations, indicating expansion of populations introduced in the 19th century and recent invasions from northern European populations (Roman 2006, Blakeslee et al. 2010, Darling et al. 2014). The invasion events of the 1980s and 1990s potentially came in ballast water of European ships docking at the Strait of Canso (Nova Scotia) port, and have subsequently introduced novel northern haplotypes to the populations along the Canadian coast. In the most recent genetic study of $C$. maenas in the Gulf of Maine, from young-of-the-year samples collected in 2007, northern haplotypes were shown to have moved south, increasing in frequency by $25 \%$ between Louisbourg, Nova Scotia and Barnstable, MA (Cape Cod) between 1999 and 2007 (Pringle et al. 2011). The evolution of this genetic cline was attributed to an asymmetrical dispersal pattern, mediated by the prevailing southbound coastal currents (Pringle et al. 2011). Recent nuclear microsatellite data revealed that the cline shift may also be due to sex-biased reproductive dynamics and population size imbalances and not solely due to dispersal (Darling et al. 2014). Regardless of the cause, alleles and haplotypes representative of the northern cline were expected to increase in frequency in populations south of Nova Scotia by $10 \%$ by 2014 in young-ofthe-year (Pringle et al. 2011).

We investigated the genetic diversity of adult $C$. maenas populations spanning the Gulf of Maine from Nova Scotia to Cape Cod and south to Long Island Sound to evaluate whether the genetics of the adult populations have also shifted. Haplotypes of a $400 \mathrm{bp}$ region of the mitochondrial cytochrome $c$ oxidase I (COI) gene were examined as a neutral marker of genetic diversity and maternal gene flow among populations, the same marker that has been previously used to study green crab population genetics (Roman 2006, Darling et al. 2008, Darling 2011, Pringle et al. 2011). Adult crabs have significant negative effects on community structure (Leignel et al. 2014). Recent studies have suggested that crabs from Maine and Canada are better foragers and predators compared to southern populations (Rossong et al. 2006, Thompson 2007, League-Pike \& Shulman 2009) and were causal in eelgrass loss in Maine during the summers of 2013 and 2014 (Neckles 2015). However, these studies did not determine the genetic background of the experimental animals, so differences in behavior or abundance cannot be linked to differences in genetics. One goal of our study was to document the adult genetic composition along the range. Of broader significance, knowledge of changes in the range at various life stages of $C$. maenas in nonnative habitats will allow for a better understanding of the complex dynamics underlying invasion in other marine species.

\section{MATERIALS AND METHODS}

\section{Sample collection}

Adult crabs Carcinus maenas (carapace width $\geq 30 \mathrm{~mm}$ ) were collected from 11 sites along the northwestern Atlantic coast from Nova Scotia to Long Island Sound (Table 1; see Fig. 1). Specimens were either collected by hand from algae-covered rocks at low tide (sites: BI, PM, CA), trapped from shallow $(<5 \mathrm{~m})$ coastal waters (sites: $\mathrm{MD}, \mathrm{MB}, \mathrm{WE}$, ES, DU, BA, and LI), or in one case, with a beach seine from a marsh (site: NS). To determine if there were differences in genetic composition across life stages at the same geographical location, young-ofthe-year, determined by a carapace width $<10 \mathrm{~mm}$ (Berrill 1982), were collected in 2014 by hand during low tide at 2 different sites in Maine: Mount Desert 
Table 1. Carcinus maenas sampling locations, mean $( \pm \mathrm{SD})$ carapace width, and collection date. See Fig. 1 for full US state names

\begin{tabular}{|llll|}
\hline ID Location & $\begin{array}{c}\text { Lat. }\left({ }^{\circ} \mathrm{N}\right), \\
\text { long. }\left({ }^{\circ} \mathrm{W}\right)\end{array}$ & $\begin{array}{c}\text { Carapace } \\
\text { width }(\mathrm{mm})\end{array}$ & $\begin{array}{l}\text { Collection } \\
\text { date }\end{array}$ \\
\hline NS Keji, Nova Scotia & $43.86,64.82$ & $49.7 \pm 5.2$ & Sep 30, 2013 \\
BI Beals, ME & $44.48,67.59$ & $36.1 \pm 6.1$ & Sep 10, 2013 \\
MD Mount Desert Island, ME & $44.45,68.32$ & $39.3 \pm 5.5$ & Sep 10, 2013 \\
PM Pemaquid Point, ME & $43.83,69.51$ & $52.1 \pm 4.3$ & Jul 2, 2014 \\
MB Montsweag Bay, ME & $43.92,69.71$ & $48.3 \pm 2.9$ & May 24, 2014 \\
CA Casco Bay, ME & $43.82,70.09$ & $37.6 \pm 16.5$ & Sep 5, 2013 \\
WE Wells, ME & $43.32,70.56$ & $39.2 \pm 5.8$ & Sep 13, 2013 \\
ES Essex, MA & $42.66,70.73$ & $40.2 \pm 2.1$ & Sep 27, 2013 \\
DU Duxbury, MA & $42.03,70.65$ & $44.2 \pm 4.7$ & Nov 18, 2013 \\
BA Barnstable, MA & $41.70,70.30$ & $46.5 \pm 3.6$ & Oct 23, 2013 \\
LI Long Island Sound, NY & $40.86,72.45$ & $52.3 \pm 7.8$ & Sep 27, 2013 \\
\hline
\end{tabular}

DnaSP v.5.10.01 (Librado \& Rozas 2009). Binomial distribution was used to determine the probability of observing particular patterns given published and predicted data.

\section{RESULTS}

Six haplotypes were found in the 275 adult crabs Carcinus maenas sampled across 11 populations (Fig. 1), caused by polymorphisms in 5 loci. In the young-of-the-year, only 2 haplotypes, haplotype 1 (a southern haplotype) and haplotype 4 (a northern haplotype), were found (Table 2). Among all haplotypes, there were 2 possible nucleotide variants per locus. All polymorphisms were silent and in the 3rd position, except for the substitution creating haplotype S1, found in 1 individual from Long Island Sound, that resulted in a change of a non-polar methionine to a polar threonine at the 80th amino acid. Haplotype 1 (GenBank accession no. AY616437) was present in all populations, with adults from Pemaquid, Montsweag, Casco, Wells, Duxbury, and Barnstable exhibiting only this singular haplotype (Fig. 1). Of the 25 adults sequenced from each site, northern haplotype 4 (GenBank: DQ523684) was found in 7 individuals from Nova Scotia, 1 from Beals, and 4 from Mount Desert Island. Northern haplotype 5 (GenBank: AY616438) was found in 4 individuals from Nova Scotia and 2 from Mount Desert Island, while northern haplotype 6 (GenBank: AY616439) was found in 4 individuals from Nova Scotia and in no other populations. Haplotype 25 (GenBank: FJ159027), originating from Norway and Sweden (Darling et al. 2008), was found in 1 Essex adult. One novel southern haplotype, S1 (GenBank: KM114884), was found in 1 individual from Long Island Sound. In the young-of-the-year, similar patterns in adult haplotypes were found for Mount Desert Island individuals, with $75 \%$ of the individuals having haplotype 1 , while $17 \%$ had haplotype 4 , and $8 \%$ had haplotype 5. In Pemaquid, where all adults were haplotype 1 , one young-of-the-year was haplotype 4 ; the remaining 24 individuals were haplotype 1.

The northern sites had the highest haplotype diversity $(h)$ in the adults: Nova Scotia had the largest $h$ (0.776), while Mount Desert Island had the second largest $h$ (0.525). Beals, Essex, and Long Island Sound all had a low level of $h(0.133)$, while all other populations had an $h$ of zero. 


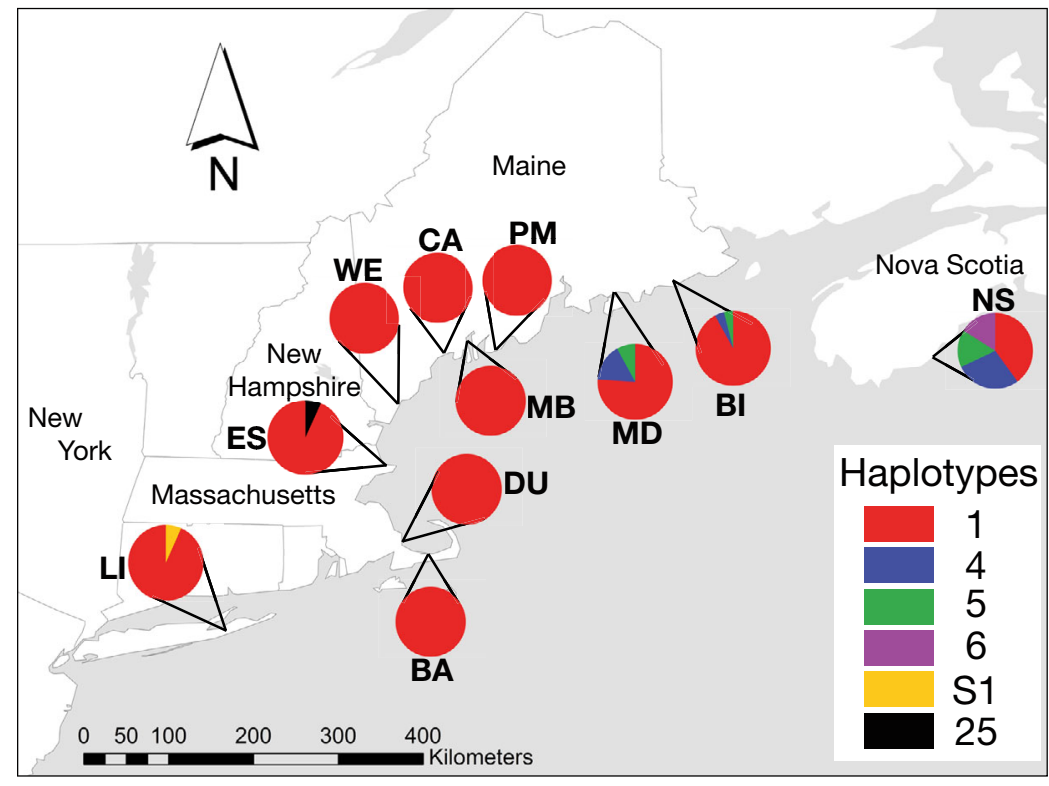

Fig. 1. Adult Carcinus maenas haplotype frequencies of a $400 \mathrm{bp}$ region of the cytochrome $c$ oxidase I $(C O I)$ gene ( $\mathrm{n}=25$ per site). Pie charts indicate proportion of haplotypes found from each population. See Table 1 for site abbreviations

4.51), due to the presence of northern haplotypes at both sites. There was a mid-level gene flow between Mount Desert Island and all other populations to the south as compared to other pairwise population comparisons (Nm: 2.2 to 3.0).

\section{DISCUSSION}

Our data reveal that the southern limit of novel northern haplotypes (4, 5 , and 6) in the adult stage of the invasive green crab Carcinus maenas is Mount Desert Island, Maine. Adult haplotype data from Nova Scotia and northern Maine (Fig. 1) is concordant with young-of-the-year data collected in 2007 (Pringle et al. 2011, Darling et al. 2014) that show extensive population admixture between northern and southern haplotypes. The lack of novel

Table 2. Carcinus maenas young-of-the-year sampling locations, haplotype(s), average carapace width $( \pm \mathrm{SD})$, and collection date. See Table 1 for site abbreviations

\begin{tabular}{|c|c|c|c|}
\hline ID & $\begin{array}{l}\text { Haplotype name } \\
\text { (\% of individuals) }\end{array}$ & $\begin{array}{c}\text { Carapace } \\
\text { width }(\mathrm{mm})\end{array}$ & $\begin{array}{l}\text { Collection } \\
\text { date }\end{array}$ \\
\hline MD & $\begin{array}{l}\text { Haplotype } 1(75 \%) \\
\text { Haplotype } 4(17 \%) \\
\text { Haplotype } 5(8 \%)\end{array}$ & $7.2 \pm 0.3$ & Jul 8, 2014 \\
\hline PM & $\begin{array}{l}\text { Haplotype } 1(96 \%) \\
\text { Haplotype } 4(4 \%)\end{array}$ & $6.9 \pm 0.2$ & Jul 2, 2014 \\
\hline
\end{tabular}

Genetic differentiation between adult populations, measured by $F_{\mathrm{ST}}$, was greatest amongst Nova Scotia versus all other populations (Table 3). Comparisons of Nova Scotia with other northern populations also show large population differentiation (Nova Scotia vs. Beals Island, $F_{\mathrm{ST}}$ : 0.445; Nova Scotia vs. Mount Desert Island, $F_{\mathrm{ST}}: 0.217$ ). There are low levels of gene flow between Nova Scotia and the populations from Casco Bay southward (Nm: 0.55 to 0.92 ). Nearly as segregated as Nova Scotia to the southern populations were the populations from Nova Scotia and Beals (Nm: 0.74). Although Mount Desert Island is farther south than Beals (by $\sim 80 \mathrm{~km}$ ), there was more gene flow between the Nova Scotia and Mount Desert Island populations (Nm: 1.92). There was a high level of gene flow between the 2 most northern Maine sites, Mount Desert Island and Beals (Nm: northern haplotypes and dominance of southern haplotype 1 in the adult stage south of Mount Desert Island (Fig. 1) is, however, surprising, given that novel northern juveniles composed $8.8 \%$ of individuals sampled along a similar geographical distribution in 2007. Using an average lifespan estimate of 4 to 7 yr (Klassen \& Locke 2007), populations of adult green crabs analyzed in our study reflect year-class recruits as far back as the last genetic study in 2007 (Pringle et al. 2011) and up to 2009. With our sample size of 250 individuals for sites south of Mount Desert Island, and an expected probability of at least 0.088 if northern young-of-the-year had survived (Pringle et al. 2011), we would have expected to sample $>8$ adult individuals with a probability of 0.999 (binomial probability: $x=8, n=250, p=0.088$ ). If the expected probability of having northern haplotypes was as low as 0.05 , we would have expected to sample $>8$ individuals with a probability of 0.930 (binomial probability: $x=8, n=250, p=0.05$ ). With statistical certainty, we can conclude that there were no northern adult haplotypes $(4,5$, and 6$)$ present in our 8 sampling sites ranging from mid-coast Maine to New York. We did, however, find 1 adult in Essex, MA, of a novel European H25 lineage (Darling et al. 2008) and 1 of a novel haplotype (S1) that has never been sequenced. While H25 has never been sequenced in North America, its presence in one Massachusetts site may have been mediated through the secondary invasion of the 1980s and 1990s and sub- 
Table 3. Pairwise $F_{\mathrm{ST}}$ values among all sites. See Fig. 1 and Table 1 for location designations

\begin{tabular}{|lccccccccccc|}
\hline & NS & BI & MD & PM & MB & CA & WE & ES & DU & BA & LI \\
\hline NS & - & & & & & & & & & & \\
BI & 0.445 & - & & & & & & & & & \\
MD & 0.217 & 0.094 & - & & & & & & & & \\
PM & 0.480 & 0 & 0.182 & - & & & & & & & \\
MB & 0.480 & 0 & 0.182 & 0 & - & & & & & & \\
CA & 0.480 & 0 & 0.182 & 0 & 0 & - & & & & & \\
WE & 0.480 & 0 & 0.182 & 0 & 0 & 0 & - & & & & \\
ES & 0.367 & 0 & 0.050 & 0 & 0 & 0 & 0 & - & & & \\
DU & 0.480 & 0 & 0.182 & 0 & 0 & 0 & 0 & 0 & - & & \\
BA & 0.480 & 0 & 0.182 & 0 & 0 & 0 & 0 & 0 & 0 & - & \\
LI & 0.462 & 0 & 0.160 & 0 & 0 & 0 & 0 & 0 & 0 & 0 & - \\
\hline
\end{tabular}

resulted in mortality or changes in connectivity between the populations. What is still unclear is whether novel northern haplotypes, at any stage, have a narrower temperature tolerance compared to their southern counterpart. Tepolt \& Somero (2014) showed that there was no difference in adult heat tolerance between crabs collected (in 2011) from Newfoundland to New Jersey. Because southern haplotype young-of-the-year had already arrived at their sample site of North Harbor, Newfoundland in 2007, and were found to be at a frequency of $59 \%$ (Blakeslee et al. 2010), there is a $99.99 \%$ chance that that at least 11 individuals (binomial probability: $x=11, \mathrm{n}=32, \mathrm{p}=0.59$ ) sampled in 2011 (Tepolt \& Somero 2014) were southern haplotypes. Our youngof-the-year data supports the environmental temperature hypothesis, whereby south of Mount Desert Island, there were northern young-of-the-year but no northern adults; at Mount Desert Island, there were both northern young-of-the-year and northern adults. However, the lack of data that connects thermal tolerance to haplotype leaves open the question of whether there actually is a difference in temperature tolerance between northern and southern haplotypes that may account for the lack of northern adults in the typically warmer waters south of Mount Desert Island (Shearman \& Lentz 2010).

The lack of northern haplotype adults could be due to a decrease or deficiency of recruitment of northern haplotypes after 2007 in the southern region of the cline. The frequency of northern haplotype youngof-the-year from Maine to New York was small in 2007, averaging $8.8 \%$ (Pringle et al. 2011). Compared to 2000, however, the frequency of the northern haplotypes in 2007 young-of-the-year increased by $25 \%$ and allele and haplotype frequency was expected to increase further in populations south of Nova Scotia by approximately $10 \%$ by 2014 (Pringle et al. 2011). It was proposed that the northern haplotypes arrived and increased in frequency in the southern region of the cline between 2000 and 2007 due to current-mediated dispersal (Pringle et al. 2011). Thus, small changes in local recruitment of novel haplotypes or a loss of northern haplotype larval input from upstream sources (Byers \& Pringle 2006, Banas et al. 2009) could have led to a decrease and eventual loss of the novel haplotypes in future young-of-the-year and would be reflected in the adult population. While the expansion of the norththe northern and southern end of the range may have 
ern haplotypes was occurring between 2000 and 2007 in the southward direction, so too was the expansion of southern haplotypes in the northward direction (Pringle et al. 2011, Darling et al. 2014). Since allelic diversity in the southern region of the range is mainly set by that of the northern, retentive, upstream edge in northern Maine and Canada (Pringle \& Wares 2007, Wares \& Pringle 2008, Pringle et al. 2011), it is possible that the transport of larvae after 2007 in the downstream direction was mainly composed of southern haplotypes. While this scenario is highly unlikely, the frequency of southern haplotype larvae each year (post-2007) may have increased to a point where northern haplotypes were lost from the larval pool and the resultant adults that we sampled in 2013 and 2014 were reflective of that change. Furthermore, if only a small founder population of northern haplotype(s) existed in each of the downstream sink populations (sampling locations from mid-coast Maine to New York), they would be subject to drift; without rapid population expansion (Tepolt et al. 2009) and additional settlement, these novel haplotypes would be lost quickly and would not have been sampled as adults in our study. While we did not collect young-of-the-year from each sampling site, young-of-the-year data from Pemaquid and Mount Desert Island also offer some support for our larval recruitment theory. In Mount Desert Island, where one quarter of the adults are of a northern haplotype, young-of-the-year follow a similar genetic pattern (Table 2). In Pemaquid, though, where $100 \%$ of the adults are southern haplotype 1 , only $4 \%$ of the young-of-the-year are a northern haplotype (Table 2). Thus, unless a steady and sufficient influx of northern larvae from a local or upstream source is maintained over time, the adult population is composed of the most dominant haplotype.

While temperature and/or recruitment may be the contributing factor(s) to the lack of adult northern haplotypes from New York to northern Maine, another potential reason for the lack of adult novel haplotypes may be that year-classes of both southern and northern haplotypes could have been completely lost post-2007 in one or more seasons. While this is merely speculative, perhaps disease, predation, and/ or temperature caused the loss. Since there is no way to accurately age green crabs (though a new method for aging crustaceans appears promising; Kilada et al. 2012), we are unable to determine the age of our crabs; we can say that our crabs were $\geq 3$ and $\leq 7 \mathrm{yr}$ old (Berrill 1982). Thus, the loss of these year-classes may have occurred from 2007 up through 2009 or 2010. Sampling in future field seasons may be able to resolve whether loss of year-classes is the cause of our observed lack of northern haplotypes south of Mount Desert Island, Maine.

The reason for the lack of adult northern haplotypes in much of the northeast US coast is not known and has not been tested, but it is likely because one or more biotic and/or abiotic factors are regulating the dispersal, recruitment, survival, and sustainability of these haplotypes across this cline. It will be important to collect data such as larval abundance and recruitment as well as physiological tolerance across life stages in light of genetic background in order to be able to better predict and measure future genetic cline changes of the green crab in marine systems.

Acknowledgements. Thank you to Brian Beal, John Brawley, Jane Disney, Dan Harrington, Chris McCarthy, Hilary Neckles, Alyssa Novak, Bradley Peterson, Pete Thayer, and Kristin Wilson for their help with sample collection. Thank you to Arnaud Germain and Ludovic Giloteaux of Maureen Hanson's lab, Cornell University, for their instruction in sequence alignment to C.L.N. Conversations between W.G.A. and A. I. Wanamaker as well as between W.G.A., L.M.W., and P. Petraitis were very helpful in developing the discussion. This project was supported by grants from the National Center for Research Resources (5P20RR016463) and the National Institute of General Medical Sciences (8 P20 GM103423) from the National Institutes of Health, by the National Oceanic and Atmospheric Administration (NOAA) through funds from Maine Sea Grant, as well as the Bates College Student Research Fund.

\section{LITERATURE CITED}

Allendorf FW, Lundquist LL (2003) Introduction: population biology, evolution, and control of invasive species. Conserv Biol 17:24-30

Audet D, Davis DS, Miron G, Moriyasu M, Benhalima K, Campbell R (2003) Geographical expansion of a nonindigenous crab, Carcinus maenas (L.), along the Nova Scotian shore into the southeastern Gulf of St. Lawrence, Canada. J Shellfish Res 22:255-263

Banas N, McDonald PS, Armstrong D (2009) Green crab larval retention in Willapa Bay, Washington: an intensive Lagrangian modeling approach. Estuar Coasts 32: 893-905

> Berrill M (1982) The life cycle of the green crab Carcinus maenas at the northern end of its range. J Crustac Biol 2: 31-39

Blakeslee $\mathrm{AMH}, \mathrm{McKenzie} \mathrm{CH}$, Darling JA, Byers JE, Pringle JM, Roman J (2010) A hitchhiker's guide to the Maritimes: anthropogenic transport facilitates longdistance dispersal of an invasive marine crab to Newfoundland. Divers Distrib 16:879-891

Byers JE, Pringle JM (2006) Going against the flow: retention, range limits and invasions in advective environments. Mar Ecol Prog Ser 313:27-41

Carlton JT (1998) Apostrophe to the ocean. Conserv Biol 12: 1165-1167 
Carlton JT, Cohen AN (2003) Episodic global dispersal in shallow water marine organisms: the case history of the European shore crabs Carcinus maenas and C. aestuarii. J Biogeogr 30:1809-1820

> Compton TJ, Leathwick JR, Inglis GJ (2010) Thermogeography predicts the potential global range of the invasive European green crab (Carcinus maenas). Divers Distrib 16:243-255

> Darling JA (2011) Interspecific hybridization and mitochondrial introgression in invasive Carcinus shore crabs. PLoS ONE 6:e17828

> Darling JA, Bagley MJ, Roman J, Tepolt CK, Geller JB (2008) Genetic patterns across multiple introductions of the globally invasive crab genus Carcinus. Mol Ecol 17: 4992-5007

> Darling JA, Tsai Y-HE, Blakeslee AMH, Roman J (2014) Are genes faster than crabs? Mitochondrial introgression exceeds larval dispersal during population expansion of the invasive crab Carcinus maenas. R Soc Open Sci 1: 140202, doi:10.1098/rsos.140202

> Dawirs RR (1985) Temperature and larval development of Carcinus maenas (Decapoda) in the laboratory; predictions of larval dynamics in the sea. Mar Ecol Prog Ser 24: 297-302

deRivera C, Hitchcock N, Teck S, Steves B, Hines A, Ruiz G (2007) Larval development rate predicts range expansion of an introduced crab. Mar Biol 150:1275-1288

> Gaither MR, Bowen BW, Toonen RJ (2013) Population structure in the native range predicts the spread of introduced marine species. Proc R Soc B 280:20130409

Kilada R, Sainte-Marie B, Rochette R, Davis N, Vanier C, Campana S (2012) Direct determination of age in shrimps, crabs, and lobsters. Can J Fish Aquat Sci 69:1728-1733

Klassen GJ, Locke A (2007) A biological synopsis of the European green crab, Carcinus maenas. Can Manuscr Rep Fish Aquat Sci 2818. Fisheries and Oceans Canada, Ottawa

Kolbe JJ, Glor RE, Schettino LR, Lara AC, Larson A, Losos JB (2007) Multiple sources, admixture, and genetic variation in introduced Anolis lizard populations. Conserv Biol 21:1612-1625

Larkin MA, Blackshields G, Brown NP, Chenna R and others (2007) Clustal W and Clustal X version 2.0. Bioinformatics 23:2947-2948

> League-Pike PE, Shulman MJ (2009) Intraguild predators: behavioral changes and mortality of the green crab (Carcinus maenas) during interactions with the American lobster (Homarus americanus) and Jonah crab (Cancer borealis). J Crustac Biol 29:350-355

Leignel V, Stillman JH, Baringou S, Thabet R, Metais I (2014) Overview on the European green crab Carcinus spp. (Portunidae, Decapoda), one of the most famous marine invaders and ecotoxicological models. Environ Sci Pollut Res Int 21:9129-9144

> Librado P, Rozas J (2009) DnaSP v5: a software for comprehensive analysis of DNA polymorphism data. Bioinformatics 25:1451-1452

Lockwood JL, Cassey P, Blackburn T (2005) The role of propagule pressure in explaining species invasions. Trends Ecol Evol 20:223-228

Nagaraj M (1993) Combined effects of temperature and salinity on the zoeal development of the green crab,
Carcinus maenas (Linnaeus, 1758) (Decapoda: Portunidae). Sci Mar 57:1-8

Neckles H (2015) Loss of eelgrass in Casco Bay, Maine, linked to green crab disturbance. Northeast Nat (in press)

Novak S, Mack R (2005) Genetic bottlenecks in alien plant species: influence of mating systems and introduction dynamics. Sinauer Associates, Sunderland, MA

- Parker IM, Simberloff D, Lonsdale WM, Goodell K and others (1999) Impact: toward a framework for understanding the ecological effects of invaders. Biol Invas 1:3-19

Pringle J, Wares J (2007) Going against the flow: maintenance of alongshore variation in allele frequency in a coastal ocean. Mar Ecol Prog Ser 335:69-84

Pringle JM, Blakeslee AMH, Byers JE, Roman J (2011) Asymmetric dispersal allows an upstream region to control population structure throughout a species' range. Proc Natl Acad Sci USA 108:15288-15293

Reitzel AM, Miner BG, McEdward LR (2004) Relationships between spawning date and larval development time for benthic marine invertebrates: a modeling approach. Mar Ecol Prog Ser 280:13-23

> Roman J (2006) Diluting the founder effect: cryptic invasions expand a marine invader's range. Proc R Soc B 273: 2453-2459

> Roman J, Darling JA (2007) Paradox lost: genetic diversity and the success of aquatic invasions. Trends Ecol Evol 22:454-464

> Rossong MA, Williams PJ, Comeau M, Mitchell SC, Apaloo J (2006) Agonistic interactions between the invasive green crab, Carcinus maenas (Linnaeus) and juvenile American lobster, Homarus americanus (Milne Edwards). J Exp Mar Biol Ecol 329:281-288

> Shearman RK, Lentz SJ (2010) Long-term sea surface temperature variability along the US East Coast. J Phys Oceanogr 40:1004-1017

> Tepolt CK, Somero GN (2014) Master of all trades: thermal acclimation and adaptation of cardiac function in a broadly distributed marine invasive species, the European green crab, Carcinus maenas. J Exp Biol 217:1129-1138

Tepolt CK, Darling JA, Bagley MJ, Geller JB, Blum MJ, Grosholz ED (2009) European green crabs (Carcinus maenas) in the northeastern Pacific: genetic evidence for high population connectivity and current-mediated expansion from a single introduced source population. Divers Distrib 15:997-1009

Thompson W (2007) Population-level effects of the European green crab (Carcinus maenas L.) in an eelgrass community of the southern Gulf of St. Lawrence. MSc thesis, University of New Brunswick, Fredericton

Vitousek PM, D'Antonio CM, Loope LL, Westbrooks R (1996) Biological invasions as global environmental change. Am Sci 84:218-228

> Wares J, Pringle J (2008) Drift by drift: effective population size is limited by advection. BMC Evol Biol 8:235

Wares J, Hughes A, Grosberg R (2005) Mechanisms that drive evolutionary change: insights from species introductions and invasions. Sinauer Associates, Sunderland, MA

Yamada S, Dumbauld B, Kalin A, Hunt C, Figlar-Barnes R, Randall A (2005) Growth and persistence of a recent invader Carcinus maenas in estuaries of the northeastern Pacific. Biol Invas 7:309-321

Submitted: September 26, 2014; Accepted: May 12, 2015 Proofs received from author(s): July 2, 2015
Editorial responsibility: Steven Morgan,

Bodega Bay, California, USA 